
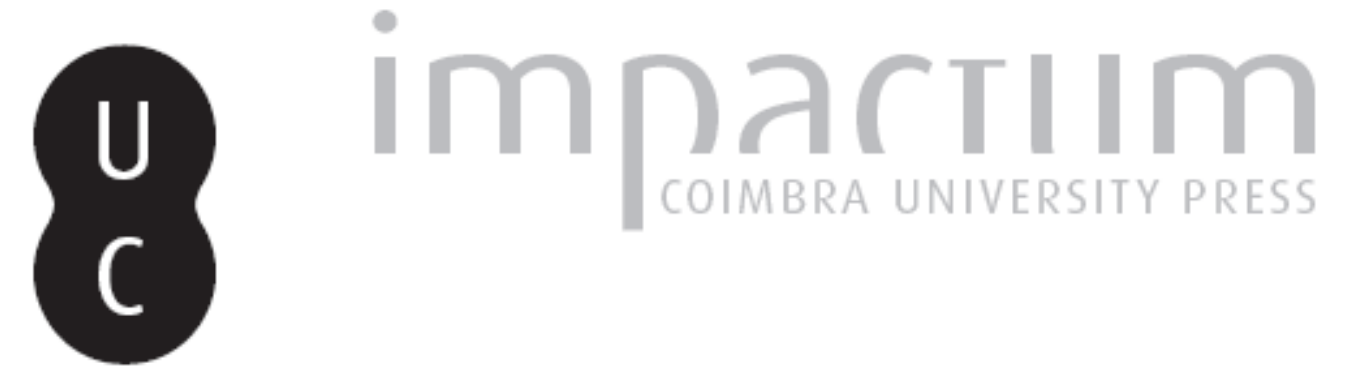

\title{
The architecture of construction
}

\section{Autor(es): $\quad$ Diamond, Rosamund}

Publicado por: Editorial do Departamento de Arquitetura

URL persistente:

URI:http://hdl.handle.net/10316.2/37267

DOI:

DOI:http://dx.doi.org/10.14195/1647-8681_4_15

Accessed : $\quad$ 26-Apr-2023 12:31:00

A navegação consulta e descarregamento dos títulos inseridos nas Bibliotecas Digitais UC Digitalis, UC Pombalina e UC Impactum, pressupõem a aceitação plena e sem reservas dos Termos e Condições de Uso destas Bibliotecas Digitais, disponíveis em https://digitalis.uc.pt/pt-pt/termos.

Conforme exposto nos referidos Termos e Condições de Uso, o descarregamento de títulos de acesso restrito requer uma licença válida de autorização devendo o utilizador aceder ao(s) documento(s) a partir de um endereço de IP da instituição detentora da supramencionada licença.

Ao utilizador é apenas permitido o descarregamento para uso pessoal, pelo que o emprego do(s) título(s) descarregado(s) para outro fim, designadamente comercial, carece de autorização do respetivo autor ou editor da obra.

Na medida em que todas as obras da UC Digitalis se encontram protegidas pelo Código do Direito de Autor e Direitos Conexos e demais legislação aplicável, toda a cópia, parcial ou total, deste documento, nos casos em que é legalmente admitida, deverá conter ou fazer-se acompanhar por este aviso.

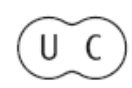




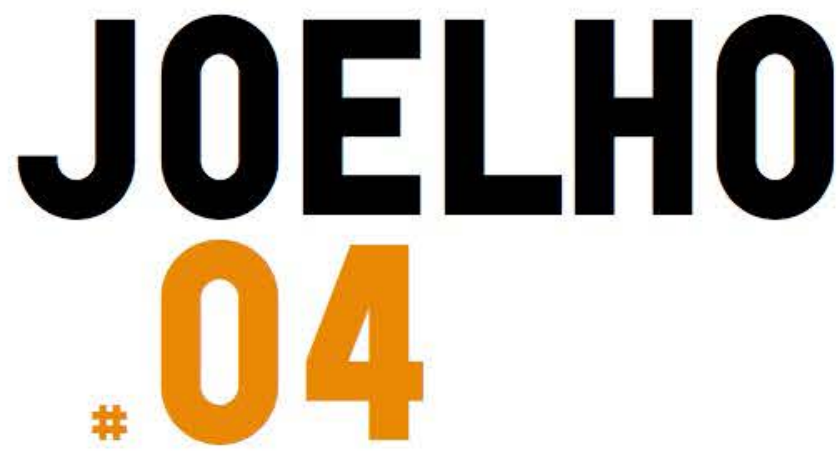

\section{ENSINAR PELO PROJETO \\ TEACHING THROUGH DESIGN}

\section{Coordenaçẫo:}

Paulo Providência

Gonçalo Canto Moniz

Alexandre Alves Costa Juan Domingo Santos Florian Beigel Philip Christou Elizabeth Hatz David Leatherbarrow Andrew Clancy Colm Moore Michael McGarry Willemijn Wilms Floet

Exposição TAPE 20Ir-12 


\section{Rosamund Diamond 'T'he architecture of construction}

\section{Introduction}

The background to this paper is my teaching of design studio (in Oxford, Bath and the Architectural Association), and of technical studies in architecture at the AA, where I ran the second and third year Intermediate School programme. Technical studies included courses on structures and other technical aspects applied to architecture, talks related to the idea of construction, full scale projects, and the work embedded in studio projects. In organising architectural education so that technique is identified as a separate component, a creative dilemma arises between space making and its technical imperatives. The design studio challenge is the facility to manipulate fields of empirical knowledge so that they converse with ideas in instinctive and experimental design. In school, certain kinds of knowledge are extracted in order to convey physical properties, but when this happens, the balance may be tipped in how studio projects develop. In architecture, the equivalent to the old question of which came first, the chicken or the egg, is the interdependency of architecture and the technical arts. As they apply to architecture, the technical arts can mean many things, including the transposition of artistic and physical labour. I use the term 'technical arts' to embody the field's breadth of influence, simultaneously alluding to a particularly British condition, the perceived gap between the sciences and arts. 'Technical arts', implies other meanings associated with their contexts, which are capable of imprinting themselves on design, to convey more than construction, potentially a whole culture, and with It the representations linked to the production of architecture. I am reminded of something John Hejduk said about the kind of architect he considered himself to be:

I was interested in the poetics of architecture, in that which only the architect can give.... I'm not an ambiguous architect; I deal with fabrications, with clarities.... the forms are there, they don't have double meanings, they're singular, any one should be able to look at them....

The painter starts with the real world and works toward abstraction, and when he's finished with a work it is abstracted from the so-called real world. The architect starts with the abstract world, and due to the nature of his work, works toward the real world. The significant architect is one who, when finished with a work, is as close to that original abstraction as he could possibly be... (Hejduk, 1985, p.63).

\section{A proposed diagram}

How do we describe the projects made in the studio, or the fabrication of built work? Might it be possible to associate different techniques with categories of architectural approach, as technical typologies? A diagram on which to map teaching and architectural projects is proposed as a way of considering how technique affects design in its ideas, fabrication and representation. This might simultaneously categorise some different teaching methods, and use examples to try to describe architecture in terms of the technical arts ${ }^{1}$. One of its starting points was Charles Jencks' 'evolutionary tree' of architectural movements. Is it possible to make an alternative to explain the state

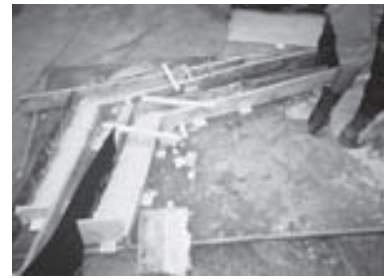

2. Concrete casting/testing, Architectural Association.

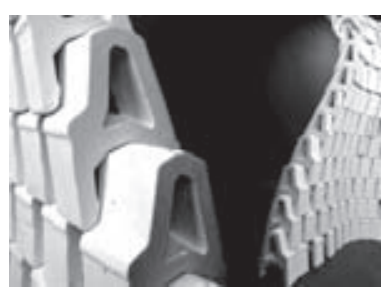

3. Studio Degree Unit A UEL Clara Kraft and Satoshi Isono, project example, Alef brick 1:1. 
of architecture through its making, a construction version of the proliferation map? The idea of a diagram associating the culture of architecture and education, to technique, arose from Kenneth Frampton's (2001) analysis of architecture in terms of building typologies in Studies in Tectonic Culture, and Gottfried Semper's (1989, 2004) identification of architecture with four elements, ascribing to each technical and symbolic properties. Technical investigations associated with architectural development could mirror the idea, become a metalanguage, or exploratory ends in themselves. Semper deduced this potential condition in his propositions about the relationship of constructional elements and their concomitant techniques to meaning in forming space, and the potential ambiguities and complexities between structure and enclosure. 'Semper...... considered architecture less technically.. than he did anthropologically and culturally. He did not espouse utilitarian ends, but rather the "embodied idea", the manner by which an era infuses its ethos on the walls of its architecture.' (Kieran, 1995, p.176).

In the diagram (fig.1), which is in a rough state, idea is presented in terms of spatial and material form, and stereotomic and tectonic typologies, with relationships of site, construction and structure. Andrea Deplazes (2008) makes a distinction between body (stereotomic) and lattice (tectonic) as the starting point of his construction handbook: Constructing Architecture: Materials, Processes, Structures. Fabrication is identified for the understanding that architectural meanings are manifest in physical acts of construction and assemblage, Semper's four architectural elements with associated technical arts are differentiated. It recognizes the craft of building and then identifies a dichotomy in relation to building skills and contemporary computerised production. Yet ascribing properties to the illustrated architects shows the complexity of trying to categorise by construction. They tend to straddle categories, for example representing the stereotomic by tectonic means, or in the construction methods used. Representation is identified for the duality of description inherent in architecture where the designer seldom makes the work, but describes how it is to be made.

The diagram could also become a speculation on whether architects chosen synthesise representation with a design process specific to their architecture. Drawings and models can represent the idea, facilitating the design process, and translating ideas into designs and their details.

\section{Examples}

Four examples of school projects overlain on the diagram, demonstrate different connections to technique in architecture. The examples, of which the first two represent general methods, are 1 Concrete casting as practical work connected to a structures course, and as phenomenological experience, 2 Model making as abstract representation or material interpretation, 3 Studios which use a building material and its techniques to develop spatial design approaches, and 4 Studio investigations into new materials, standardised components and industrialised techniques. The examples

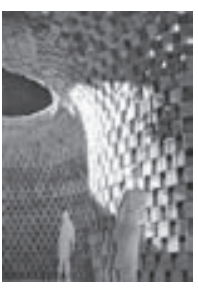

4. Studio Degree Unit A UEL Clara Kraft and Satoshi Isono, project example, Alef brick 1:20.

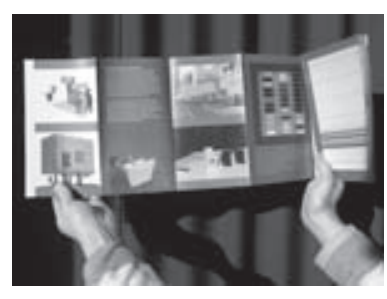

5. Open book, Off the Shelf, DRMM. of teaching type are discussed alongside some prominent architects, intimating the use of precedents as references, whilst trying to categorise approaches to fabrication in the context of space making, its ideologies and representation. The school examples identify aspects of the relationship of factual properties to intuitive creativity and how physical properties imbue design with meaning. In the studio, technical explorations can enhance design investigations, or risk losing central ideas to the mechanisation of their making. One of the teaching studio's purposes lies in its free yet rigorous experimentation with the technical arts. In Britain, this can exist across all kinds of studios, from the seemingly abstract to the most singular material investigators. The purpose of the discussion is how to evolve ways of realising studio projects such that they reveal and manipulate meaningful intention through conscious fabrication, in a link between thinking and making which is fundamental.

\section{1}

Structural studies are typically the most theoretical, factually based courses. In the Architectural Association (and other schools), they are simultaneously presented by lecture and by physical testing. (fig.2) These include the casting of concrete used to test and precisely measure structural behaviour in its crushing properties, as conditions of stability and failure. Lessons in structural properties, presenting universal knowledge, become personal discoveries of craft to form. The qualities of the concrete manifest the testable properties of the material and its physical nature through its manufacture and the outcomes, as actions and temporary representations. As a studio material, concrete is also cast into forms, full size elements in relation to the body, used as building models, to experiment with the idea of fabrication and its expressions. Precise structural testing raises issues of the effects of scale as they are discerned in all models, while full scale experiments reveal other unknown or unpredictable characteristics not only of the material but the process.

\section{2}

One type of design studio uses as a starting point a focus on material and its fabrication, traditionally and innovatively, as a way of developing architectural form. One recent example is the second and third year unit of Clara Kraft and Satoshi Isono at the University of East London. (fig. 3, 4) Last year, they focussed on brick as a cast material, deriving alternative building techniques in the context of local conditions, whilst investigating concomitant form making. Having investigated the architecture and construction methodologies of four precedents, students made 1:1 prototypes using computerised fabrication and their own castings. Their development of the prototypes, was connected to their experiencing the processes of forming and firing, as thinking to making. The means of production was connected to the fundamental and creative conditions of brick with its latent crafting, through representation and the hand.

I am reminded of this approach considering two recent projects by O'Donnell and Tuomey Architects, exhibited in the 2012 Venice
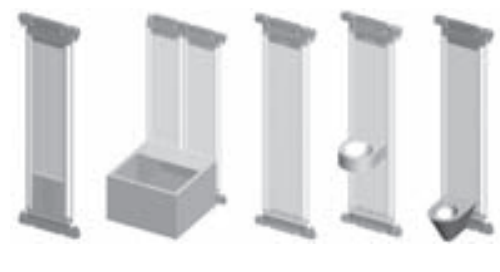

6. Intermediate Unit AA DRMM, project example, Michael Spooner, tech colour components. 
Biennale: their timber Vessel installation with modelled iterations, shown alongside models and drawings of their LSE Students' Union building which is under construction. Form making is investigated through the brick skin of the LSE and the fabrication of the Vessel, from timber blocks. Brick appears in the LSE conceived stereotomically, reconstituted as a tectonic skin like enclosure, composed of dozens of special brick shapes, crafted by their computer drawings.

\section{3}

Another type of studio has developed projects from investigations into new materials and elements, reinventing existing materials, or using standard building component catalogues. The Intermediate Unit DRMM ran at the Architectural Association, encouraged students to develop solutions from research and the prototyping of materials and components, and live construction. (fig.5, 6) Their methodology of inventive assembly and a reassessment of existing spatial conditions, has fed into a practice approach in which the architecture is derived from the material and the crafting of its details (DRMM, 20O1).

Themes of craft and form recur in Frank Gehry's work, spanning between his own house and the Guggenheim Bilbao. The house remakes its spatial form by cutting and refabricating, crafting and reinventing off the peg materials, as if the elaboration of the connections can fulfil the architect's desire for direct involvement in the construction. By the Guggenheim, three dimensional computer modelling results in a much iterated form making, annealed to the techniques of representation. Simultaneously, the sophistication of the computer tools has replaced an idea of hand crafting materials, with precise manufacturing systems, with their more predictable, controlled outcomes. There is a generation of approach which has been enabled by computer analysis, in which the material takes precedence, with its abstracted conception alongside the building's idea, in the sense that the fabrication is no longer a simultaneous characteristic of the architecture.

\section{4}

Model making can catalyse projects via techniques connecting thought to process in physical prototypes which resist generic construction as applied investigations. Drawings and models have the dual purpose of facilitating the design process itself and translating ideas into designs and their details. In the world of constructing with intent and desire, representation is significant, all representations, the drawing, the computer rendition, the model, handmade or cnc fabricated, are discussions of material construction. One universal kind, of the classic buff card hand modelling $(f i g .7,8)$ represents spatial characteristics and tectonic properties as developmental studies, neither as scaled copy or simulacrum. The models can be abstracted representations or embody the thinking to making as a way of looking at issues of form and material together. One precedent is Siza's method of designing through sketches and models, with the direct relationship of the idea to its physical expression in the context of its making. Take for example the Galician Centre of Contemporary Art in Santiago and the Ibere Camargo Foundation in Porto Alegre, building outside Portugal, raising the idea of universal approaches and local differences. The card models, describing the sculptural mass of the building, with the floating ramps above its base, represent a direct relationship to fabrication, where material ideas are so embedded in form, that the models resemble the toilets associated with dressmaking in which the structure is inherent in the essence of the thing.

There is another kind of studio model in which characteristics of a project are described by making a different, complementary object, an alternative artefact. Examples are the models made by Tom Emerson's Cambridge students, in which casting and layering generate models of intuitive simulacra, in which the purpose of the model detaches itself from the building to record an idea. Or the exercise by David Grandorge's Diploma 7 students at London Metropolitan University of interpreting seven housing types in the work of Pierre d'Avoine Architects (fig. 9, 10). The models, in which secondhand tables were adapted and altered, reappropriated the concept of the dollshouse, to understand and interpret essential architectural ideas in the houses. In school projects, the model in its iterations and different forms is an important component of incomplete development where the means maybe as useful, or more so than the ends

Architecture is a mediated practice in the sense that architects rarely build their own work. The techniques of the architect are elaborated in the methodology of construction, and its representation. What Hejduk identified, was the potential of the methods of making buildings to sustain or conflict with originary intent. In this way technical explorations could mirror the idea, or become a metalanguage, or become exploratory ends in themselves. Hejduk's question refers to meaning in architecture and its authentic pursuit in fabrication. What these studio and project examples lead us back to is the idea of whether the material should carry its own independent message detached from the work. The examples cannot answer a particular way of investigating material in the studio, only raising the complexity technique embeds in our projects.

\footnotetext{
$1 \rightarrow$ The diagram is at a very developmental stage. With many names and projects missing. It includes a few examples of different approaches to teaching technique and examples of architects/their projects.
}

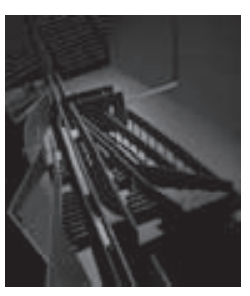

7. Intermediate Unit AA, Andrew Houlton, Patrick Lynch, project example, Jaen Taek Park, Conjured Landscape, Naples.

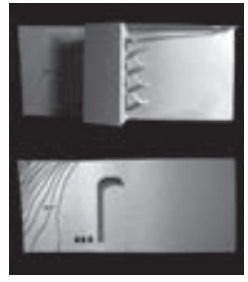

8. Intermediate Unit AA, Andrew Houlton, Patrick Lynch, project example, Jaen Taek Park, Conjured Landscape, Naples, sections.

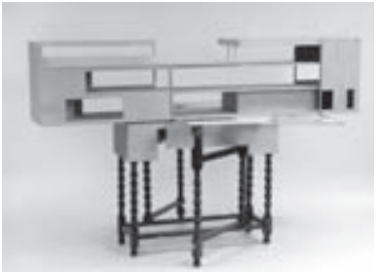

9. Diploma Unit 7 LMU, David Grandorge, project examples, Maria Kalivati, Peter Lee, Arthur Smart, Big House.

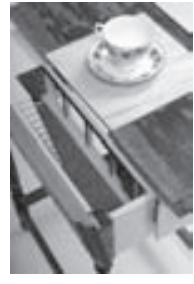

10. Diploma Unit 7 LMU, David Grandorge, project examples, Lucy Gardner, Gerson Magoga, Ahmad Mohmmed, Barbera Stewart, Invisible House. 


\begin{tabular}{|c|c|c|c|c|c|c|c|c|c|c|}
\hline & $\begin{array}{l}\text { STOON/ } \\
\text { nesencor }\end{array}$ & & & & & $\begin{array}{l}\text { Medelling } \\
\text { M, Londoe Met }\end{array}$ & 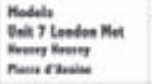 & thin 4 Beser MA & $\begin{array}{l}\text { Suah / hoes } \\
\text { Brich Stodlo itt }\end{array}$ & $\begin{array}{l}\text { Bepleise trins Stedis } \\
\text { ITi }\end{array}$ \\
\hline & Ancinten & 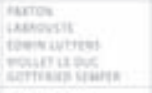 & 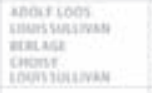 & 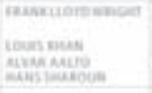 & 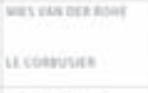 & 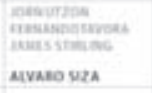 & astorsonst & 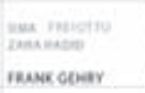 & 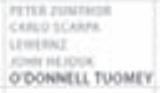 & 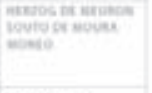 \\
\hline & mern & Gathe Burpe & & 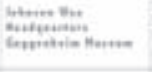 & 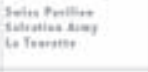 & "rostom, & & 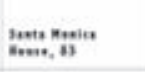 & & 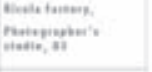 \\
\hline \multirow{2}{*}{ ites } & tertien & $\begin{array}{l}\text { STEREOTOMIC } \\
\text { Body }\end{array}$ & & & & 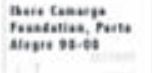 & & & 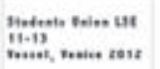 & \\
\hline & $\begin{array}{l}\text { material } \\
\text { expressien }\end{array}$ & $\begin{array}{l}\text { TECTONic } \\
\text { Lentice }\end{array}$ & & & & 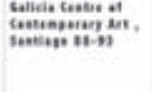 & & 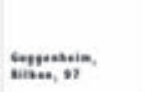 & & \\
\hline \multirow{5}{*}{ Pasticatias } & Dements & & \multicolumn{2}{|c|}{ HEARTH } & \multicolumn{2}{|c|}{ MOUND } & \multicolumn{2}{|c|}{$200 \%$} & \multicolumn{2}{|c|}{ EACADE } \\
\hline & Tocteinal Rots & entied ats & \multicolumn{2}{|c|}{$\begin{array}{l}\text { Carnaia } \\
\text { dey } f \text { eats }\end{array}$} & \multicolumn{2}{|c|}{ Maseny } & \multicolumn{2}{|c|}{ Conestry } & \multicolumn{2}{|c|}{ Tentilen } \\
\hline & Hasd mon & crefted & 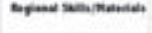 & 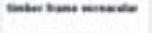 & & & \multicolumn{2}{|c|}{ ears } & & \\
\hline & Modisu mole & 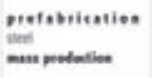 & & & & $\begin{array}{l}\text { batas } \\
\text { marsats }\end{array}$ & & 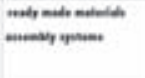 & & 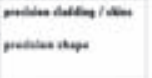 \\
\hline & Presendar & mintivs & & & & & & & & \\
\hline \multirow[b]{2}{*}{ atombtstatise } & senows: & & 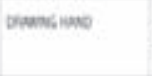 & $\begin{array}{l}\text { nockise, } \\
\text { nura ow }\end{array}$ & $\begin{array}{l}\text { astans } \\
\text { mover }\end{array}$ & & & 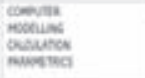 & thes coentat & \\
\hline & $\begin{array}{l}\text { whatwess } \\
\text { Theceis } \\
\text { suatres }\end{array}$ & 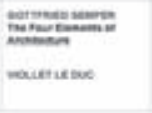 & & 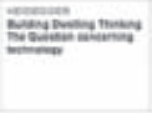 & 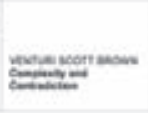 & 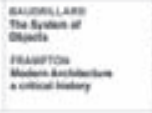 & 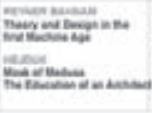 & 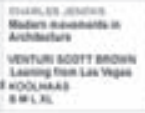 & 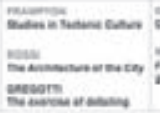 & 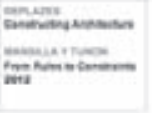 \\
\hline
\end{tabular}

1. Preliminary architecture-technical arts diagram, Rosamund Diamond.

\section{Bibliographical References}

Hejduk, J. (1985). "The Poetics of Architecture", in K. Shkapich (ed.), Mask of Medusa: works, 1947-1983, New York: Rizzoli.

-

Frampton, K. (2001). Studies in Tectonic Culture: The Poetics of Construction in Nineteenth and Twentieth Century Architecture, Cambridge Mass.: MIT Press.

Semper, G. (1989). The Four Elements of Architecture and Other Writings. Cambridge: Cambridge University Press. Trans. Harry F. Mallgrave and Wolfgang Herrmann.
Semper, G. (2004). Style in the Technical and Tectonic Arts; or, Practical Aesthetics. Santa Monica: Getty Publications. Trans. Harry F. Mallgrave.

-

Kieran, K. (1995). “Building Character: Modern Construction Beyond Determinism in the Work of Frank Lloyd Wright and Louis Kahn', 9H, 9, On Continuity, 174-191.

Deplazes, A. (2008). Constructing Architecture: Materials, Processes, Structures; a Handbook, Basel: Birkhauser.
DRMM (2001), Off the Shelf, book and exhibition, London: AA. 